\title{
ACUTE RHINOSINUSITIS DURING THE SWIMMING SEASON - ETIOPATHOGENESIS, DIAGNOSTIC APPROACHES AND TREATMENT
}

\author{
Sergiy M. Pukhlik, Oleg F. Melnicov, Anatoly P. Shchelkunov, Olga V. Titarenko \\ Odessa National Medical University, Odessa, Ukraine \\ Corresponding author: Odessa National Medical University, Valichovsky prov., 2, 65026, Odessa, Ukraine, \\ e-mail: lor@te.net.ua
}

\begin{abstract}
Background: A significant increase of acute rhinosinusitis, mainly maxilloethmoiditis, occurs during the summer season in Ukrainian resort areas, particularly in Odessa.

Material and methods: 106 patients with acute "bathing" rhinosinusitis (ABRS) were examined in terms of microbiology, immunology, and allergy during 3 summers (2008-2010). The control group consisted of 51 patients who developed acute purulent rhinosinusitis during the "nonbathing" season.

Results: In the case of ABRS, fungi and mycotoxins were found to damage the mucous membranes of the nose and paranasal sinuses, making ABRS aggressive and fast. It occurred against a background of lowered immunity and sensitization.

Conclusions: Traditional therapy for ABRS can quickly eliminate inflammation, but sensitization to mold remains high, leaving the possibility of re-development of inflammation. Incorporation of interferon inducers and anti-allergy agents substantially improves clinical and immunological indices of treatment efficacy.
\end{abstract}

Key words: acute "bathing" rhinosinusitis • diagnosis • treatment

\section{ОСТРЫЙ РИНОСИНУСИТ ВО ВРЕМЯ КУПАЛЬНОГО СЕЗОНА - ЭТИОПАТОГЕНЕЗ, ПОДХОДЫ ДИАГНОЗА И ЛЕЧЕНИЕ}

\section{Резюме}

Введение: Большое внимание заслуживает рост случаев острого риносинусита, главным образом гаймороэтмоидитного, во время летнего сезона в курортных зонах, особенно в Одессе.

Материал и методы: 106 пациентов с острым "купальным" риносинуситом (ABRS) были обследованы с помощью
микробиологических, иммунологических, аллергологических методов в течение 3 летних сезонов (2008-2010).
Контрольная группа состояла из 51 пациента с острым гнойным риносинуситом во время "некупального" сезона.

Результаты: В случае ABRS грибы и микотоксины имеют вредное воздействие на слизистые оболочки носа и придаточные пазухи носа. Их действие является причиной более агрессивного течения ABRS. Это происходит на фоне снижения иммунитета и повышения чувствительности пациентов.

Выводы: Традиционная терапия ABRS может быстро удалить воспаление, но повышенная чувствительность остается высокой, что не исключает возможности повторного возникновения воспаления. Совмещение индукторов интерферона и антиаллергенов во время лечения значительно улучшает клинические и иммунологические показатели эффективности лечения.

Ключевые слова: острый "купальный" риносинусит • диагноз • лечение 


\section{RINOSINUSITIS AGUDA DURANTE LA TEMPORADA DE BAÑO - ETIOPATOGÉNESIS, ENFOQUES DE DIAGNÓSTICO Y TRATAMIENTO}

\section{Extracto}

Introducción: Es del interés especial un aumento significativo de rinosinusitis aguda, principalmente del típo de maxiloetmoiditis, en verano en las áreas de recurso, en particular en Odessa.

Material y métodos: Los 106 pacientes con la rinosinusitis aguda de "baño" (ABRS) fueron examinados con la ayuda de los métodos microbiológicos, inmunológicos, alergologicos durante 3 temporadas de verano (2008-2010). El grupo de control consistió de 51 pacientes con rinosinusitis purulenta aguda durante la temporada "no bañadora".

Resultados: En caso de ABRS los hongos y micotoxinas tienen un efecto perjudicial en las membranas mucosas de la nariz y senos paranasales. Su efecto hace la duración de ABRS más agresiva. Esto ocurre en el contexto de inmunidad inferior y sensibilización de pacientes.

Conclusiones: La terapia tradicional de ABRS puede eliminar rápidamente la inflamación, pero la sensibilización a los moldes permanece alta, que no excluye la posibilidad de surgimiento de la inflamación una vez más. El uso de los inductores de interferón junto con los antialérgenos considerablemente mejora índices clínicos e inmunológicos de la eficacia de tratamiento.

Palabras claves: rinosinusitis aguda de "baño" • diagnóstico • tratamiento

\section{Background}

Despite the improvement in diagnosis and treatment of purulent sinusitis, its prevalence has not diminished. Moreover, the inflammatory pathology of the paranasal sinuses keeps rising, and there is an increase of recurrent and chronic forms of the disease [1-3]. A significant increase of acute sinusitis is noted during winter-time influenza epidemics $[4,5]$.

Of special interest, a significant increase in acute rhinosinusitis, mainly maxilloethmoiditis occurs during the summer season in Ukrainian resort areas, particularly in Odessa. In this case, the number of those who need emergency medical care increases 10 -fold. The number of cases rises sharply in the hot season, after bathing. Doctors call this sinusitis "bathing" or "marisinusitis", as patients typically associate the disease with previous bathing and the possibility that the sea water was contaminated. A lot of cases arise among newly arrived guests.

The term "acute bathing rhinosinusitis" (ABRS) has been offered by us because in the medical literature there appears to be no description of such a disease. In Odessa, medical practitioners call the outbreak of acute rhinosinusitis which occurs after a long time spent on the beach and sea bathing "marine sinusitis". We believe that this term can be applied to all acute purulent rhinosinusitis of different localization (maxilloethmoiditis, frontitis, hemisinusitis, pansinusitis, etc.) which develops in patients sensitive to mold fungi (mainly Aspergillum). Young and middle age patients develop these forms of rhinosinusitis during the hot season (August, September) and it typically has a rapid beginning, without any previous viral respiratory manifestations.

It is generally accepted that acute purulent rhinosinusitis develops as a complication of viral diseases, in view of the damaging action of viruses on mucous membrane of the nose and the addition of bacterial flora [6-8]. It can be assumed that in the case of marine sinusitis the damaging effect of viruses on the mucous membranes of the nose and paranasal sinuses (PNS) is initiated by fungi, their spores and mycotoxins. Their effect on mucous membranes is aggressive and develops with lightning speed. The damage on the mucous membrane by fungi and Gram-positive flora produces the purulent character of the sinusitis [9].

Typical ABRS symptoms are difficulty in nasal breathing, violent pain in the injured paranasal sinuses, and high temperature. Nasal discharge is initially purulent. The diagnostic criteria of ABRS include the following: exposure or sensitization to mold fungi, mainly Aspergillum (skin probes, laboratory examination); general and specific allergenic fungi; eosinophilia of peripheral blood and nasal mucus; and lowering of interferon and abnormal content of ciliated epithelium cells in nasal discharge.

The reasons for such outbreaks and the necessary preventive measures that should be taken both by the medical service and the population to prevent the disease are of scientific and practical interest.

The aim of this investigation was to reduce the incidence of acute "bathing" rhinosinusitis in the summer season by developing preventive measures.

\section{Materials and methods}

The observations were made during 3 seasons (2008-2010). Exactly 106 patients with ABRS were examined with the help of microbiological methods in the coastal zone of Odessa in the summer. As a control group, 51 patients with acute purulent rhinosinusitis (APRS) developed during the "nonbathing" season (winter-spring) were examined (Tables 1-4, Figure 1). In addition, 20 healthy subjects as well as 20 patients with APRS were examined immunologically. 
Table 1. Age and sex of patients.

\begin{tabular}{|c|c|c|c|c|}
\hline \multirow{2}{*}{$\frac{\text { Age, years }}{\text { Sex }}$} & \multicolumn{2}{|c|}{ ABRS } & \multicolumn{2}{|c|}{ APRS } \\
\hline & $M$ & $\mathbf{F}$ & $M$ & $\mathbf{F}$ \\
\hline $18-25$ & 30 (28.5\%) & 23 (21.7\%) & 11 (21.6\%) & 9 (17.6\%) \\
\hline $26-35$ & 19 (17.9\%) & 11 (10.4\%) & $10(19.6 \%)$ & 11 (21.6\%) \\
\hline $36-45$ & $8 \quad(7.5 \%)$ & $6 \quad(5.7 \%)$ & $4 \quad(7.8 \%)$ & $4 \quad(7.8 \%)$ \\
\hline $46-55$ & $3 \quad(2.8 \%)$ & $2 \quad(1.9 \%)$ & - & - \\
\hline $56-60$ & $2 \quad(1.9 \%)$ & $2 \quad(1.9 \%)$ & - & $2 \quad(3.9 \%)$ \\
\hline Totals & $62(58.5 \%)$ & 44 (41.5\%) & 25 (49.0\%) & $26 \quad(51 \%)$ \\
\hline
\end{tabular}

Table 2. Distribution of patients in the main and control groups according to the severity of ABRS.

\begin{tabular}{|c|c|c|c|c|}
\hline Degree of severity & \multicolumn{1}{c|}{ ABRS } & \multicolumn{1}{c|}{ APRS } & $\boldsymbol{p}$ & $\boldsymbol{t}$ \\
\hline Light (isolated effect on one PNS) & $8(8 \%)$ & $10(18 \%)$ & 0.05 & 1.7 \\
\hline Medium (effect on two PNS) & $26(24 \%)$ & $21(42 \%)$ & 0.07 & 0.3 \\
\hline Severe (effect on more than two PNS) & $72(68 \%)$ & $20(40 \%)$ & 0.07 & 3.4 \\
\hline
\end{tabular}

Table 3. Characteristics of ABRS and APRS patients' complaints.

\begin{tabular}{|c|r|r|r|r|}
\hline Symptoms & ABRS & APRS & $\boldsymbol{p}$ & $\boldsymbol{t}$ \\
\hline Nasal obstruction & $106(100 \%)$ & $37(72 \%)$ & 0.03 & 4.4 \\
\hline Nasal discharges & $97(94 \%)$ & $31(61 \%)$ & 0.05 & 6.8 \\
\hline Pain in region of PNS & $83(78 \%)$ & $30(60 \%)$ & 0.06 & 4.6 \\
\hline Cough & $19(18 \%)$ & $41(80 \%)$ & 0.05 & 10.1 \\
\hline
\end{tabular}

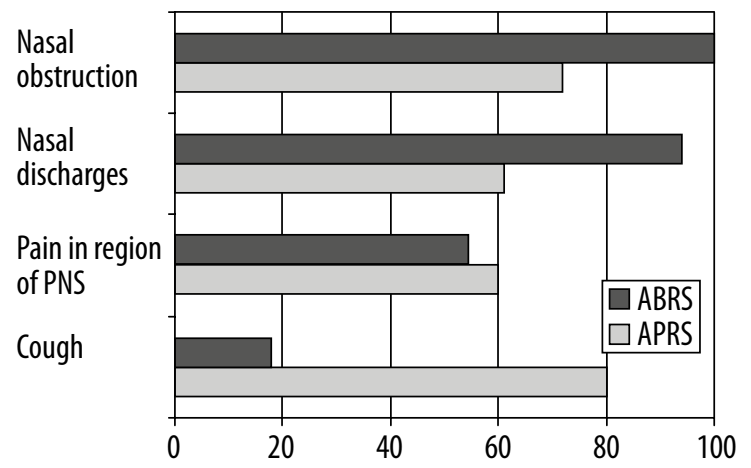

Table 4. Distribution of patients according to duration of the disease (from first symptoms to visit to the doctor).

\begin{tabular}{|c|c|c|c|c|c|c|}
\hline \multirow{2}{*}{$\begin{array}{c}\text { Duration of disease, } \\
\text { days }\end{array}$} & \multicolumn{2}{|c|}{ ABRS } & \multicolumn{2}{|c|}{ APRS } & \multirow[b]{2}{*}{$p$} & \multirow[b]{2}{*}{$t$} \\
\hline & $\begin{array}{l}\text { Number of } \\
\text { patients }\end{array}$ & $\begin{array}{l}\text { Percent of } \\
\text { patients }\end{array}$ & $\begin{array}{l}\text { Number of } \\
\text { patients }\end{array}$ & $\begin{array}{l}\text { Percent of } \\
\text { patients }\end{array}$ & & \\
\hline$<5$ & 80 & 75.5 & 0 & 0.0 & 0.03 & 18.0 \\
\hline $6-8$ & 19 & 17.9 & 13 & 25.5 & 0.06 & 1.07 \\
\hline $9-11$ & 3 & 2.8 & 21 & 41.2 & 0.05 & 5.3 \\
\hline $12-14$ & 4 & 3.8 & 14 & 27.4 & 0.05 & 3.8 \\
\hline $15-20$ & 0 & 0.0 & 3 & 5.9 & 0.06 & 0.6 \\
\hline
\end{tabular}




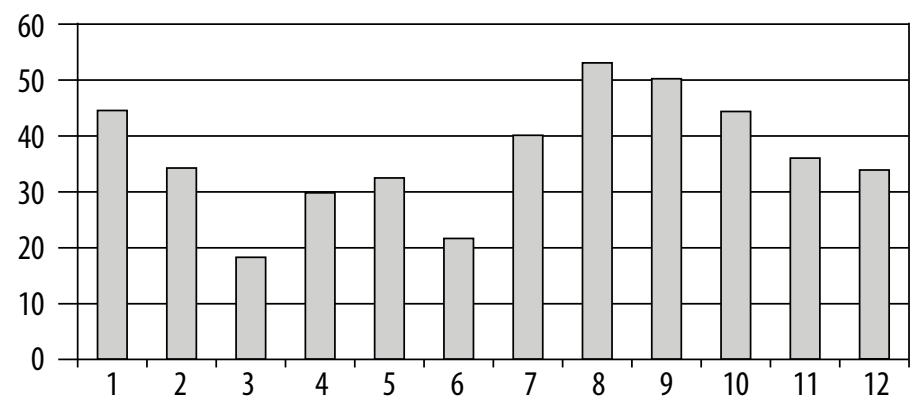

Figure 1. Number of patients with acute rhinosinusitis, by month of year

Table 5. Taxonomic spectrum of bacteria isolated from patients with ABRS.

\begin{tabular}{|c|c|c|c|c|c|}
\hline \multirow{2}{*}{$\begin{array}{c}\text { Genus (according to } \\
\text { Burgy, 1997) }\end{array}$} & \multirow{2}{*}{ Species } & \multicolumn{3}{|c|}{ Number of isolated strains } & \multirow{2}{*}{$\begin{array}{c}\text { Significance of } \\
\text { difference to control } \\
\text { group }\left(\chi^{2}\right)\end{array}$} \\
\hline & & Abs. & $\%$ & $\pm \Delta(95)$ & \\
\hline \multirow{4}{*}{ Staphylococcus } & S. aureus & 42 & 36.6 & 9.3 & 0.145 \\
\hline & S. epidermidis & 12 & 11.3 & 6.0 & 0.002 \\
\hline & S. haemolyticus & 28 & 26.4 & 8.4 & 0.774 \\
\hline & S. saprophyticus & 0 & & & 0.133 \\
\hline Esherichia & E. coli & 13 & 12.3 & 6.2 & 2.304 \\
\hline Proteus & & 8 & 7.5 & 5.0 & 2.712 \\
\hline Streptococcus & & 47 & 44.3 & 9.5 & 0.074 \\
\hline Klebsiella & & 5 & 4.7 & 4.0 & 1.227 \\
\hline Providencia & & 7 & 6.6 & 4.7 & 0.021 \\
\hline
\end{tabular}

The microflora in discharges from the nasal cavity and paranasal sinuses of patients with ABRS and APRS in the autumn-winter period who were treated in the ENT Department of City Hospital was studied.

Allergy tests to fungal allergens were made using the skinprick test. Reactions were evaluated after 30 minutes and 24 hours.

Immunological studies were performed in the Pathophysiology and Immunology Laboratory of the Kiev Institute of Otolaryngology of Prof. A. I. Kolomiychenko.

\section{Results}

\section{Clinical aspects of marisinusitis}

The beginning of ABRS is usually lightning fast, without any prodromal symptoms. There is severe headache, fever, difficult nasal breathing, and profuse purulent discharge from the nose appearing against a background of general overall health. The rapid onset and purulent inflammation from the first day makes us think that this form of acute rhinosinusitis is originally purulent and requires immediate antibiotic therapy.

Microbial results from the nose and paranasal sinuses in patients with bathing rhinosinusitis

In total, 304 strains were isolated from patients with ABRS (106) and 129 strains were isolated in people from control group (51). All isolated strains had typical phenotypical characteristics. Taxonomic analysis of the examined bacterial strains showed 6 types: Staphylococcus, Escherichia, Klebsiella, Proteus and Providencia. The types of Staphylococcus, which occurred most often, were classified according to species: S. aureus, S. haemolyticus, and S. epidermidis (Table 5).

Comparison of inoculation from the nasal cavity and from sea water according to standard bacterial contamination showed no correlation. The high percentage of mold fungi Aspergillum (75.4 $\pm 8.2 \%)$ isolated from ABRS patients makes us think that ABRS can be induced by fungal flora and that fungi play a leading etiologic role (Table 6).

Statistics show that the main and control groups differ positively only in the frequency of isolation of Aspergillum niger $(75.4 \pm 8.2 \%$ in the main group and $17.3 \pm 10.3 \%$ in the control group). Confidence intervals do not overlap; the confidence of the difference $\chi^{2}=45.6$, i.e. the difference is highly significant with error less than $1 \%$.

One more difference of microbic cenosis in the main and control group is the correlation of dominant and minor components. In the main group the species of microscopic fungi Aspergillum niger dominated, the subdominant group consisted of Candida albicans, S. aureus and Streptococcus spp. The rest of the species made up minor components.

In the control group the species of microscopic fungi Candida albicans dominated, the subdominant group was represented 
Table 6. Microscopic fungi species isolated from patients with ABRS.

\begin{tabular}{|c|c|c|c|}
\hline Species & Aspergillum niger & Candida albicans & Yeast \\
\hline Absolute number & 80 & 57 & 4.7 \\
\hline$\%$ & 75.4 & 53.8 & 4.0 \\
\hline$\pm \Delta_{(95)}$ & 8.2 & 9.5 & 1.23 \\
\hline $\begin{array}{c}\text { Significance of differences } \\
\left(\chi^{2}\right)\end{array}$ & 45.64 & 0.97 \\
\hline
\end{tabular}

* Confidence of difference to control group.

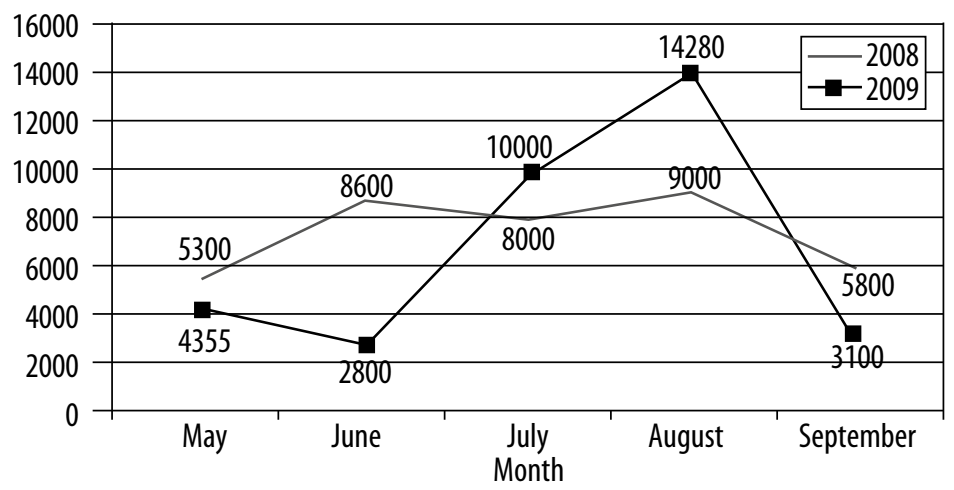

Figure 2. Index of lactose positive E. coli.

by $S$. aureus, $S$. haemolitycus and $S$. spp. In most cases from 2 to 5 microbial associations were isolated from patients.

We initiated an examination of sea water and sand for the presence of fungi. It was found that sea water contained a small number of fungi (mold and yeast). The sea sand on practically all beaches contained mold (in greater degree) and yeast (in smaller degree). It was noted that the number of fungi increased in the sea sand by the end of the season, which correlates with the increased number of patients with acute rhinosinusitis in August and September.

\section{Study of sea water}

Using data from the sanitary station which examines the bacterial composition of seawater and sand on the coast of Odessa (the samples were taken once a week), sea water at depths of 5 and 50 meters was investigated with the following index: lactose positive coli, E. coli, Enerococcus, Staphylococcus, Colifagus (Figure 2).

Thus, for virtually the entire holiday season the bacterial background of sea water did not go beyond the norm! This is important to emphasize, because some patients attribute their illness to the polluted sea. It is gratifying to note that the purity of the sea water is increasing year to year; this is due to a reduction in many polluting industries and improvement of sewage treatment facilities. Despite these improvements, the frequency of rhinosinusitis during the bathing season increases. In part, this may be due to an increased number of tourists, but this is not particularly noticeable.

\section{Our assumptions}

Seawater and sea sand has never been investigated for the presence of fungi. Clear parameters of fungal contamination of seawater and marine sand do not exist. We were the first to propose that fungi - molds and yeast - are present in the seawater and sand.

According to pre-existing data, there are fungi in sea sand at practically all beaches, molds in significant numbers and yeast in smaller numbers. There is a sharp rise in the number of fungi in the sea sand by the end of the season, which corresponds to the rise in the number of patients in August and September.

\section{Revealed sensitization}

The most important parameter in the systemic factors of immunity and allergy was the change in specific antibody levels to fungal allergens. The content of total IgE in the serum of ABRS patients examined was 8-10 times higher than in the control group (Table 7, Figure 3).

\section{Immunological studies}

The most important parameter in the system factors of immunity and allergy was the change, both general and specific, to fungal allergens antibodies level. Besides, the decrease of regulatory cytosine and antivirus factor of interferon takes place, which can indirectly indicate changes in the differentiation of T-helpers (Th) towards Th2 cells, prompting the formation of immune reactions against fungal flora. The appearance of raised levels of ciliated epithelium cells in such patients supports the assumption that fungal flora promote destructive processes in the mucous. The results of allergology investigations show that the high level of "allergy background" is typical for marine sinusitis, and the hypothesis of a pathogenetic role of allergy in the genesis of the disease can be put with a great degree of probability. 
Table 7. Content of specific IgE to fungal allergens in blood serum of examined groups.

\begin{tabular}{|c|c|c|}
\hline \multirow{2}{*}{ Allergens } & \multicolumn{2}{|c|}{ Multiplicity of degranulation compared with control, $\mathbf{M} \pm \mathbf{m}$} \\
\cline { 2 - 3 } & Control & ABRS \\
\hline Candida & $1.5 \pm 0.2$ & $3.7 \pm 0.8^{\star}$ \\
\hline Penicillum & $1.7 \pm 0.3$ & $3.3 \pm 0.7$ \\
\hline Aspergillum & $2.1 \pm 0.6$ & $4.7 \pm 1.1^{\star}$ \\
\hline
\end{tabular}

* Significantly to control $(<0.05)$.

A

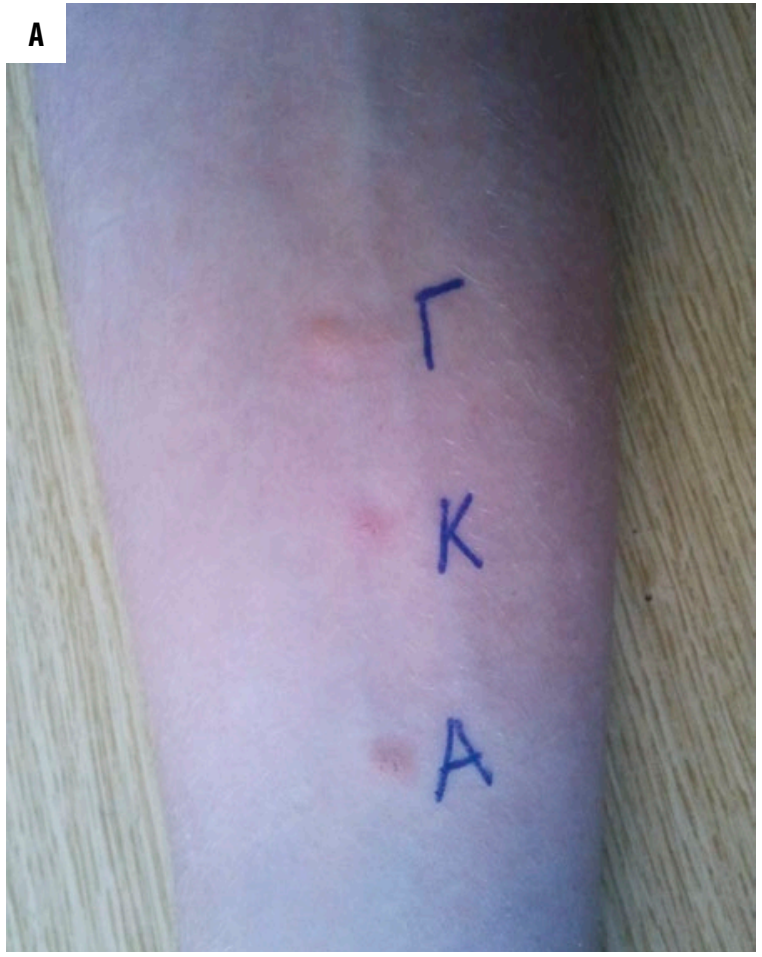

B

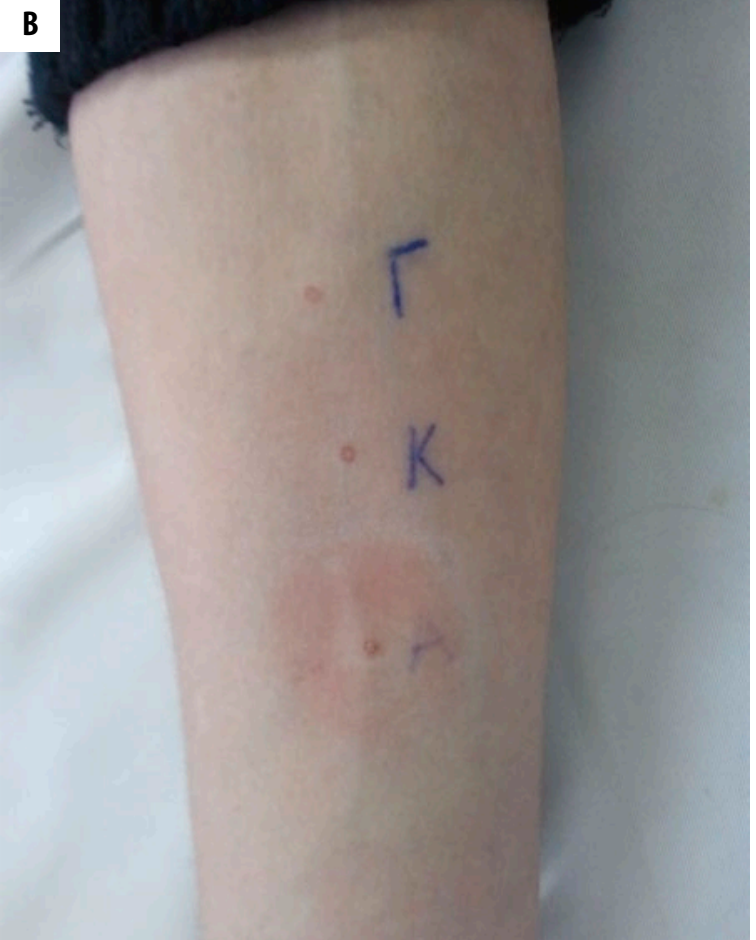

Figure 3. Skin tests with fungal allergens. (A) After 30 minutes. (B) After 24 hours.

Table 8. Contents of reagins in the blood serum of the examined patients.

\begin{tabular}{|c|c|c|c|}
\hline \multirow{2}{*}{ Groups } & \multirow{2}{*}{ Reagins } \\
\cline { 3 - 4 } & & $\mathbf{I g ~ E , ~ I U / m /}$ & Ig G4, g/l \\
\hline Control & 10 & $46.7 \pm 10.2$ & $2.8 \pm 0.6$ \\
\hline APRS & 10 & $101.9 \pm 4.1$ & $3.1 \pm 0.9$ \\
\hline ABRS & 10 & $343.4 \pm 9.5$ & $3.7 \pm 1.0$ \\
\hline
\end{tabular}

In our case, temporary lowering of immunity takes place because of a number of reasons: high solar radiation (most patients spent much time in the sun and had sunburn to various degrees), sharp change of climate (visitors from other regions), relaxed diet, stress of cold water on the body, etc. It is important to note that the lowering of immunity was temporary; the mycotic lesion ended in damage of mucous membranes of nose and PNS (the places of fungal penetration) and joining of bacterial flora.

The most important parameter in the system factors of immunity and allergy was the changing of the level of reagins, both general and specific, with respect to fungal allergens. The conducted therapy of ABRS showed that the level of general IgE in the patients' blood serum was lowered almost to the physiological norm (104.2 IU/ml), while the level before the treatment was $343.3 \mathrm{IU} / \mathrm{ml}$, i.e. 3 times more (Table 8).

The levels of specific IgE to fungal antigens in patients with marine sinusitis also showed positive dynamics after the treatment, and though they didn't reach the control values (Table 9), they were certainly lower than before the treatment. 
Table 9. Contents of IgE specific to fungal allergens in blood serum of examined groups.

\begin{tabular}{|c|c|c|c|}
\hline \multirow{2}{*}{ Allergens } & \multicolumn{3}{|c|}{ Degranulation divisibility over control, $\mathbf{M} \pm \mathbf{m}$} \\
\cline { 2 - 4 } & Control & ABRS before the treatment & ABRS after the treatment \\
\hline Candida & $1.5 \pm 0.2$ & $3.7 \pm 0.8^{*}$ & $2.4 \pm 1.0$ \\
\hline Penicillum & $1.7 \pm 0.3$ & $3.3 \pm 0.7$ & $2.3 \pm 0.6$ \\
\hline Aspergillum & $2.1 \pm 0.6$ & $4.7 \pm 1.1^{*}$ & $3.0 \pm 0.9$ \\
\hline
\end{tabular}

${ }^{*}$ Confidence level to control $(<0.05)$.

Table 10. Contents of interferon in the blood serum of patients with ABRS.

$\gamma$-interferon

\begin{tabular}{|c|c|c|c|c|}
\hline \multirow{2}{*}{ Groups } & \multicolumn{4}{|c|}{ Statistics } \\
\cline { 2 - 5 } & Average, pg/ml & $\begin{array}{c}\text { Limits of variation } \\
\text { (min-max) }\end{array}$ & $\begin{array}{c}\text { Number of } \\
\text { examinations }\end{array}$ & $\begin{array}{c}\text { Confidence of } \\
\text { differences }\end{array}$ \\
\hline Control & 11.2 & $5-30$ & 12 & - \\
\hline After treatment & 5.0 & $1.5-10$ & 14 & $<0.001$ \\
\hline Before treatment & 0 & 0 & 14 & $<0.001$ \\
\hline
\end{tabular}

$\alpha$-interferon

\begin{tabular}{|c|c|c|c|c|}
\hline \multirow{2}{*}{ Groups } & \multicolumn{4}{|c|}{ Statistics } \\
\cline { 2 - 5 } & Average, pg/ml & $\begin{array}{c}\text { Limits of variation } \\
\text { (min-max) }\end{array}$ & $\begin{array}{c}\text { Number of } \\
\text { examinations }\end{array}$ & $\begin{array}{c}\text { Confidence of } \\
\text { differences }\end{array}$ \\
\hline Control & - & $2-8$ & 12 & - \\
\hline After treatment & 4.5 & $1-8$ & 14 & $>0.05$ \\
\hline Before treatment & 1.2 & $0-3$ & 14 & $<0.01$ \\
\hline
\end{tabular}

The most important factor in the interferon status of the patients with ABRS was the lowering of both types of interferons, $\alpha$ - and $\gamma$-interferon, to practically zero values. After treatment, partial restoration of $\alpha$-interferon and the appearance of immune $\gamma$-interferon in the blood were noted, which is nowadays considered to be a prognostically favorable sign (Table 10).

The reconstruction of the level of Interleukin-10 controlling the development of inflammatory reaction should also be considered as a positive sign.

\section{Cytological studies}

The appearance in patients with ABRS of a high concentration of cells from the ciliated epithelium may be evidence in favor of the hypothesis that in patients with APRS the fungal flora contributes more to destructive processes in the mucosa than does the microflora.

Thus, ABRS is characterized by:

- The presence of severe mucosal colonization by fungi, predominantly Aspergillum niger, combined with the presence of IgE-sensitization to fungi and low levels of $\alpha$ - and $\gamma$-interferon in serum and oropharyngeal secretions.
- Reduced $\gamma$-interferon and increased content of cells from the ciliated epithelium can be a guide to a diagnosis of acute bathing season rhinosinusitis.

\section{Treatment}

It should be noted that ABRS was well treated before, even without understanding the causes of the disease. The main method was, and continues to be, puncture with lavage of the sinuses with an antiseptic solution and the introduction of antibiotics and hormone drugs [10]. Probably, stopping bathing is important (contact with the causative allergen). The lightning speed of ABRS calls for immediate antibiotic therapy, and is due to the great damaging effect of fungi, spores, and mycotoxins on the mucous membranes of the nasal cavity and paranasal sinuses, together with the rapid addition of bacterial flora. The basic therapy, typical for patients suffering from common acute bacterial rhinosinusitis, is antibiotics, mucolytics, decongestants, antihistamines and/or hormones) [11-13]. We also assigned an inductor of interferon - Cycloferon (systemic) - which is used for 7-10 days from the onset of the disease.

The conducted ABRS therapy showed that the levels of total IgE in the serum of patients fell to the physiological norm. 
The levels of specific IgE to fungal antigens in ABRS patients also showed a positive trend, although they did not reach the control level. After treatment, a partial recovery of $\alpha$-interferon and the appearance of immune $\gamma$-interferon in the blood was registered, which according to the modern view is a prognostically favorable sign.

We did not notice any complications from medicinal therapy. There were no cases of disease relapse outside the season in 43 patients who were monitored for one year.

Thus we assume that the use of complex treatment of patients with ABRS is pathogenetically justified, and the immunological parameters indicate that patients normalize after treatment. These findings correlate with improvement in the patients' health, and allow us to consider these indicators as good objective criteria in assessing the effectiveness of treatment of patients with ABRS.

We managed to trace people who have suffered from ABRS in the past. We found that:

- They do not suffer from chronic or recurrent sinusitis and feel good in the autumn-winter period; however, sensitization to mold remains.

- Re-contact and a powerful inflow in significant number of this mold to the body can cause ABRS again.

\section{Discussion}

It is generally accepted that acute rhinosinusitis develops as a result of the course of viral diseases and their complications, because of the damaging effect of viruses on the mucous membranes of the nose and paranasal sinuses and additional bacterial flora [14]. We can assume that in the case of ABRS, fungi, their spores and mycotoxins have a damaging effect of viruses on the mucous membranes of the nose and paranasal sinuses. Their effect on mucous membranes appears to be more aggressive (fungi are bigger than viruses and bacteria, fungi are capable of rapid reproduction, they release large quantities of spores and mycotoxins), which makes the onset of ABRS lightning fast. It occurs against a background of lower immunity due to increased insolation, relaxed diet, change of climatic conditions, exposure to cold water on the body, etc., apparently making visitors to Odessa suffer from it more often [15].

This long-term study of the causes, features and peculiarities of ABRS revealed the previously undescribed mechanism of purulent sinusitis, which occurs in healthy individuals sensitized to mold infection (genus Aspergillum), in conditions of high insolation and overheating, often because of stress associated with a visit to another city in different climatic zone. The source of mold is sea sand and, to a lesser degree, sea water. Developing immunological changes in systemic and local immunity contribute to the invasion of the bacterial flora and the rapid development of purulent rhinosinusitis with a severe clinical picture [16]. Such a mechanism of development of sinusitis has not previously been described. Traditional therapy of purulent sinusitis using the puncture method of treatment, local and systemic antibiotics, and local hormone therapy can quickly eliminate the inflammation, but sensitization to mold remains high, which does leave open the possibility of re-development of inflammation. Cases of chronic sinusitis were not observed. Research in this direction must continue.

\section{References:}

1. Безшапочний СБ, Лобурець ВВ: Ендоскопічна ендоназальна функціональна хірургія: достоїнства, недоліки, перспективи. Ринологія, 2002; 2: 3-10

2. Лайко АА, Бредун ОЮ, Яновська ВГ: Інфекції в хронічній патології навколоносових пазух у дітей (попередне повідомлення). Журн. вушних, носових і горлових хвороб, 2004; $1: 40-43$

3. Пискунов ГЗ: Клиническая ринология. МИА, 2006; 542

4. Сергеев Д.В. Об этиологии острых синуситов. Российская оториноларингология. 2003; 1: 129-31

5. Alho OP: Paranasal sinus bony structures and sinus functioning during viral colds in subjects with and without a history of recurrent sinusitis. Laryngoscope, 2003; 113: 2163-68

6. Заболотний ДІ, Плаксивий ОГ, Кухарчук ОЁ: Аутокоїдні медіатори запалення та патогенетичне обгрунтування лікування хворих на гострий та хронічний гнійний гайморит. Журн. вушних, носових і горлових хвороб. 1997; 2: $1-7$

7. Леснова ОА: Возбудители верхнечелюстного синусита у пациентов, направленных на стационарное лечение. Росс, ринол, 2002; 2: 103-5

8. Окунь ОС, Колесникова АГ: Эпидемиологический анализ хронического гнойного гайморита. Рос. ринология, 1997; 1: $17-26$
9. Naclerio RM: Etiologic Factors in Inflammatory Sinus Disease. In: Diseases of the Sinuses: Diagnosis and Management. Kennedy DW, Bolger WE, Zinreich SJ (eds.), Hamilton. 2001; Chapter 4: 47-56

10. Заболотный ДИ, Яремчук СЭ: Место амоксиклава при антибиотикотерапии инфекционных воспалительных заболеваний ЛОР-органов: Метод. рекомендации. К., 2003; 28

11. Chiu AG: Medical Management of Chronic Rhinosinusitis. In: Sinusitis From Microbiology to Management. Brook I, ed. New York, 2006; Chapt. 11: 219-32

12. Stalman WA et al: Determinants for the course of acute sinusitis in adult general practice patients. Postgrad Med J, 2001; 77 ; 778-82

13. Wormald PJ: Treating acute sinusitis. Aust Prescr, 2000; 23: 39-42

14. Jackman AH, Kennedy DW: Pathophysiology of Sinusitis. In: Sinusitis From Microbiology to Management. Brook I, ed., New York, 2006; Chapt.6: 109-34

15. Hoover GE, Newman LJ, Platts Mills TA et al: Chronic sinusitis: risk factors for expensive disease. J Allergy Clin Immunol, 1997; 2: 185-91

16. Lacroix JS, Ricchetti A, Lew D: Symptoms and clinical and radiological signs predicting the presens of pathogenic bacteria in acute rhinosinusitis. Acta. Otolaryngol, 2002; 122(2): $192-96$ 